\title{
Identification of Meloidogyne Species from the Central Valley of Chile and Interaction with Stone Fruit Rootstocks
}

Pablo Meza, Braulio Soto, and Luis Rojas, Instituto de Investigaciones Agropecuarias, Centro Regional La Platina, La Pintana, Santiago, Región Metropolitana, Chile; and Daniel Esmenjaud, ISA, INRA, Université de Nice-Sophia Antipolis, CNRS, 06900 Sophia Antipolis, France

\begin{abstract}
Meza, P., Soto, B., Rojas, L., and Esmenjaud, D. 2016. Identification of Meloidogyne species from the Central Valley of Chile and interaction with stone fruit rootstocks. Plant Dis. 100:1358-1363.

Root-knot nematodes (RKN; Meloidogyne spp.) are predominant polyphagous pests of crops in the Central Valley of Chile. Twenty RKN populations from this region were collected from diverse crops and subsequently identified with both sequence-characterized amplified region and isoenzyme markers. Populations included three RKN species: Meloidogyne ethiopica (75\%), M. javanica (15\%), and M. arenaria (10\%). This is the first report of the high prevalence and wide host range of M. ethiopica in Chile. The host status of three Prunus rootstocks for isolates obtained from the Chilean RKN populations was then evaluated. Rootstocks assessed included the peach rootstock Nemaguard and the plum rootstock Marianna 2624, both previously considered resistant, and the peach rootstock Pomona as a susceptible accession. In the first experiment, rootstocks were inoculated individually in pots with 10,000 second-stage juveniles and eggs of each isolate, and reproduction and

galling were evaluated 5 months after inoculation. In the second experiment, the six most aggressive $\mathrm{RKN}$ isolates were used in a mixture to evaluate the host response of the same three rootstocks. No RKN were detected on Marianna 2624 in both experiments, which confirmed its immune host status to $M$. arenaria and $M$. javanica; this is the first report of immunity to M. ethiopica. Even though Pomona was classified overall as susceptible, the response of this rootstock to the RKN isolates was highly variable and ranged from susceptible to resistant, depending on the RKN isolates. Nemaguard ranged from resistant (to each of the most aggressive isolates and to their mixture) to highly resistant (to $M$. arenaria isolates). Our results illustrate that Prunus rootstocks express different levels of resistance to RKN species. RKN resistance may be active either at the isolate level (as in Pomona), at the species level (as in Nemaguard toward M. javanica and M. arenaria), or at the genus level (as in Marianna 2624).
\end{abstract}

Meloidogyne spp. (root-knot nematodes [RKN]) are economically the most important group of plant-parasitic nematodes worldwide, attacking nearly every crop species (Abad et al. 2008; Nyczepir and Esmenjaud 2008; Pinochet 2009; Skantar et al. 2008). In Prunus spp. crops (nurseries and orchards), Meloidogyne spp. are estimated to cause $15 \%$ loss in vigor and yield on a worldwide basis (VerdejoLucas and Talavera 2009). Until recently, control of plant-parasitic nematodes was achieved through the use of fumigant and nonfumigant nematicides. However, the negative environmental impacts of nematicides have led to the elimination or restricted use of most of these compounds, highlighting the urgent need for safer nematode management alternatives (Esmenjaud et al. 1997; Perry et al. 2009; Radwan et al. 2012). One of the most economically and environmentally sound methods for managing RKN damage is selecting or developing rootstocks with resistance to RKN (Esmenjaud et al. 1997; Fernández et al. 1994; Khallouk et al. 2011; Nyczepir and Esmenjaud 2008; Pinochet 1997; Pinochet et al. 1999; Verdejo-Lucas and Talavera 2009).

The stone fruit (Prunus spp.) industry is very important in Chile and stone fruits, together with grape and apple, are the most important export commodities. Stone fruits are produced in the Central Valley of Chile, where they account for $80 \%$ of the national fruit production area distributed into four Chilean administrative regions. Like in other countries where intensive stone fruit industries are established, Prunus orchards are under pressure from plant-parasitic nematodes, particularly Meloidogyne spp. (González 2007; Magunacelaya and Dagnino 1999; Mella and Sotomayor 2005). However, prevalence of Meloidogyne spp. in Chile, particularly in the stone-fruit-producing

Corresponding author: P. Meza; E-mail: pablo.meza@inia.cl

Accepted for publication 1 March 2016.

http://dx.doi.org/10.1094/PDIS-11-15-1331-RE

(C) 2016 The American Phytopathological Society regions, and their impacts on Prunus orchards are still poorly understood. This poor understanding of the host suitability of Prunus planting material is illustrated by rootstocks such as clonal accessions of Myrobalan plum (Prunus cerasifera) and cherry (P. mahaleb), which were introduced into Chile as resistant to Meloidogyne spp. After planting these accessions, plants were found with roots heavily galled and corresponding high population densities of Meloidogyne spp. (González 2007). Indeed, host suitability evaluations of Prunus rootstock material must be considered a priority due to the variability of RKN species and populations from the stone-fruit-producing areas. Additionally, evaluations must consider the high variability among the Prunus spp. in resistance to RKN. Rootstocks may carry RKN resistance genes such as those already identified in Myrobalan plum (the complete-spectrum Ma gene; Claverie et al. 2004, 2011), in peach (the RMia gene, conferring a more restricted spectrum; Claverie et al. 2004; Duval et al. 2014), and in almond (the RMja gene, conferring also an incomplete spectrum; Van Ghelder et al. 2010). The objectives of this study were to (i) identify the RKN species found in the Central Valley of Chile on a diversity of crops and (ii) determine the host suitability of three Prunus rootstocks to these RKN.

\section{Material and Methods}

Nematode material: origin, collection, and identification. Twenty soil and root samples were collected along the Central Valley of Chile (Fig. 1; Table 1). Samples were collected in fields previously identified as having Meloidogyne spp. infestations (P. Meza, unpublished data). Samples were collected from diverse crops, including vegetables (tomato and cucumber; 10 samples), grapevine (5 samples), and fruit trees (peach, cherry, and kiwi: 5 samples).

On average, the sampling area within fields was approximately $100 \mathrm{~m}^{2}$ and, within each of these areas, 10 samples were collected. At each sampling location, a soil sample down to $40 \mathrm{~cm}$ was collected directly in the root zone of the host plant with an auger or shovel; associated roots were also collected. Samples within an area were combined and a subsample of $2 \mathrm{~kg}$ of soil with associated roots was retained and transported to the laboratory. Plant-parasitic nematodes 
were extracted from a 250-g subsample of soil by decant sieving followed by the Baermann funnel method (Christie and Perry 1951). Eggs were obtained from roots using a $0.1 \% \mathrm{NaOCl}$ solution (Hussey and Barker 1973). Extracted second-stage juveniles (J2) and eggs were suspended in water and used to inoculate tomato plantlets of the susceptible 'Calace' (Imporagro, Chile) grown in sterilized soil under greenhouse conditions $\left(27 \pm 2^{\circ} \mathrm{C}, 16 \mathrm{~h}\right.$ of light and $8 \mathrm{~h}$ of darkness). After 3 months, galled roots were harvested and five single egg masses were recovered from the roots of each sample (population). Each single egg mass was used to inoculate one tomato plant to obtain a pure isolate (clonal line). After 2 to 3 months, for each population, isolates were identified as described below. If all isolates from a population (initial sample) belonged to the same species, only one isolate was retained as the representative isolate of this population.

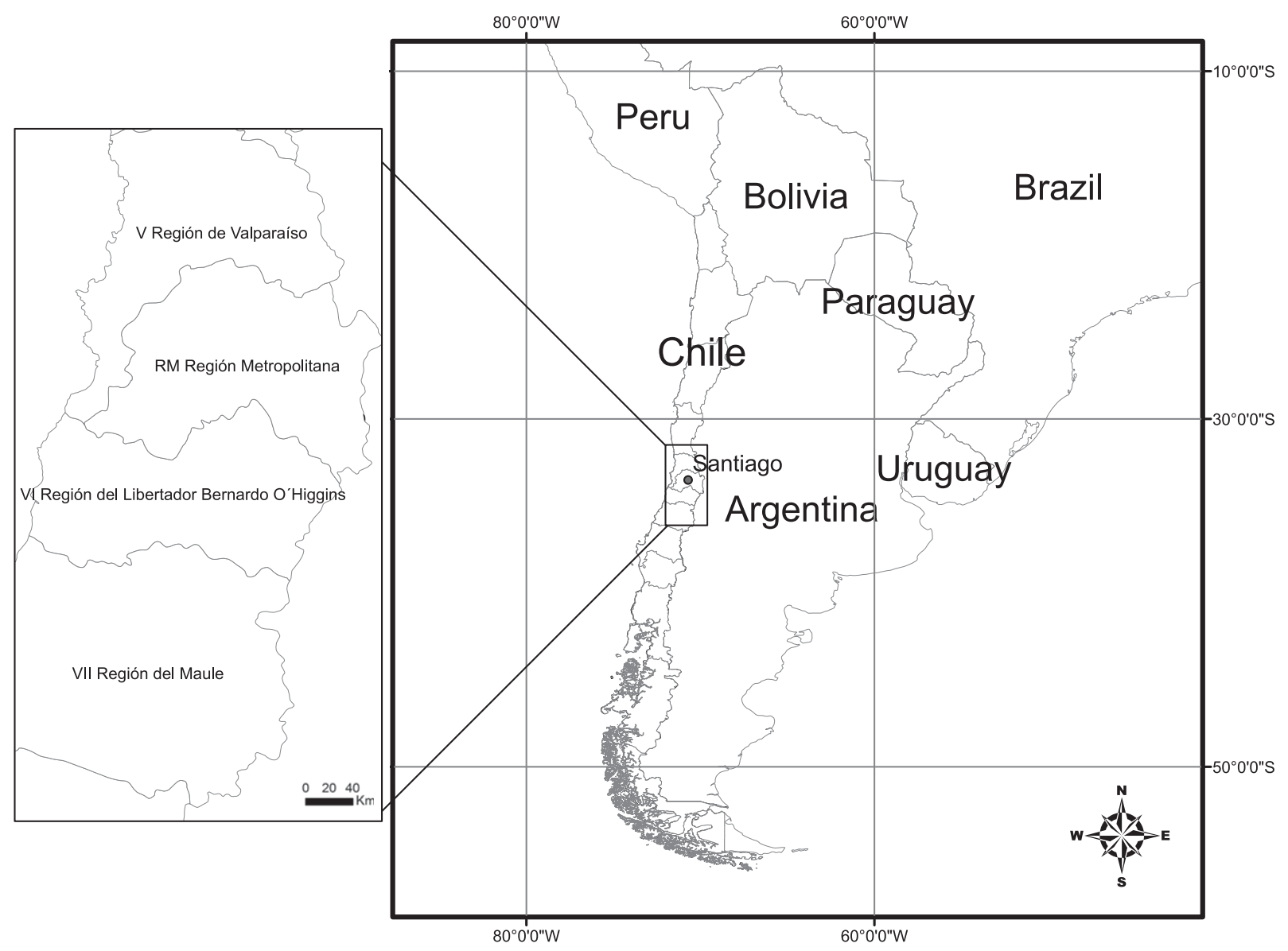

Fig. 1. Location of the four regions where most of the stone fruit are grown in Chile.

Table 1. Original host, geographic origin, and identity of Meloidogyne spp. isolates obtained from Chilean population samples and used in this study

\begin{tabular}{|c|c|c|c|}
\hline Host & Locality, region ${ }^{z}$ & Meloidogyne spp. & Code \\
\hline Grape (Vitis vinifera) & La Vinilla, V & Meloidogyne arenaria & ma1 \\
\hline Tomato (Solanum lycopersicum) & Quillota, V & M. arenaria & ma2 \\
\hline Tomato & Mallarauco, RM & M. javanica & mj1 \\
\hline Tomato & Santa Victoria, RM & M. javanica & mj2 \\
\hline Grape & Codigua, RM & M. javanica & $\mathrm{mj} 3$ \\
\hline Tomato & San Vicente de Tagua-Tagua, VI & M. ethiopica & me1 \\
\hline Tomato & San Fernando, VI & M. ethiopica & me2 \\
\hline Grapevine & Totihue, VI & M. ethiopica & me3 \\
\hline Tomato & Choapinos, VI & M. ethiopica & me4 \\
\hline Grape & Casablanca, V & M. ethiopica & me5 \\
\hline Grape & Alhué, RM & M. ethiopica & me6 \\
\hline Kiwi (Actinidia chinensis) & Naicura, VI & M. ethiopica & me7 \\
\hline Grape & Nancagua, VI & M. ethiopica & me8 \\
\hline Tomato & Champa, RM & M. ethiopica & me9 \\
\hline Tomato & San Vicente de Tagua-Tagua, VI & M. ethiopica & me10 \\
\hline Cucumber (Cucumis sativus) & Malloa, VI & M. ethiopica & me11 \\
\hline Sour cherry (Prunus cerasus) & Totihue, VI & M. ethiopica & me12 \\
\hline Sour cherry & Choapinos, VI & M. ethiopica & me13 \\
\hline Tomato & Teno, VII & M. ethiopica & me14 \\
\hline Peach (Prunus persica) & Rengo, VI & M. ethiopica & me15 \\
\hline
\end{tabular}

${ }^{\mathrm{z}}$ Chilean regions: $\mathrm{V}=$ Región de Valparaiso, RM = Región Metropolitana, VI = Región del Libertador Bernardo O'Higgins, and VII= Región del Maule. 
This representative isolate was then increased on tomato to produce inoculum for subsequent rootstock evaluation.

Specific identification of all Meloidogyne isolates was performed in two successive steps using molecular and biochemical techniques, respectively. For the first step, sequence-characterized amplified region polymerase chain reaction (PCR) markers were used (Zijlstra 2000; Zijlstra et al. 2000). Primers used were those for the species Meloidogyne incognita, M. arenaria, M. javanica, M. hapla, M. chitwoodi, and M. fallax. M. ethiopica (Whitehead 1968), a species recently redescribed by Carneiro et al. (2007) for which no specific primers have yet been developed, was not included in this set. DNA was extracted from single mature females (Meza et al. 2011). Next, the electrophoretic pattern for the esterase b (EST b) isozyme of each isolate and, notably, in the M. ethiopica isolates was determined (Dalmasso and Bergé 1978). The reference profiles (phenotypes) defined by Carneiro et al. $(2000,2007)$ served for classification of isozyme patterns.

Plant material and evaluation procedure. Resistance evaluation was performed for three rootstocks accessions: Pomona peach $(P$. persica), considered as the susceptible reference, and Nemaguard peach $(P$. persica $\times P$. davidiana) and Marianna 2624 plum $(P$. cerasifera $\times P$. munsoniana), used as resistant rootstocks (Nyczepir and Esmenjaud 2008). The host response of rootstocks was evaluated in two successive tests. In the first test, 3-month-old plants $(50 \mathrm{~cm}$ high) were obtained from El Tambo (El Tambo, VI Region, Chile) and from Agromillora Sur (Molina, VII Region, Chile) nurseries and repotted in 4-liter plastic pots filled with sterilized sandy soil in October 2013. Four weeks after planting, J2 and eggs were extracted from cultured tomato plants as described above and suspended in water. Each plant was inoculated with 10,000 individuals (J2 + eggs) per pot in a volume of $40 \mathrm{ml}(250 \mathrm{eggs}+\mathrm{J} 2 / \mathrm{ml})$. Inoculum was delivered into four 2-cm-deep holes placed $2 \mathrm{~cm}$ from the stem of the plant. Plants were maintained under greenhouse conditions $(27 \pm$ $2{ }^{\circ} \mathrm{C}, 16 \mathrm{~h}$ of light and $8 \mathrm{~h}$ of darkness), watered daily or as needed, and fertilized with Osmocote Plus (15N-9P-12K + magnesium and micronutrients; Everris Company, USA), a slow-release fertilizer. Each rootstock and isolate combination was replicated five times. Plants were harvested 5 months after inoculation. The top of the plant was cut and removed, the content of the pot was emptied, and the root system was recovered and gently washed with water. The number of galls per root system was determined visually and
A

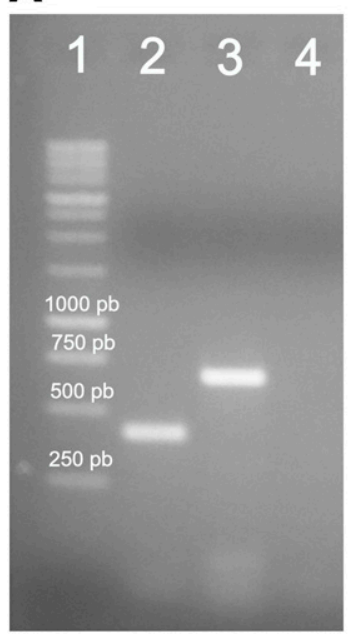

B

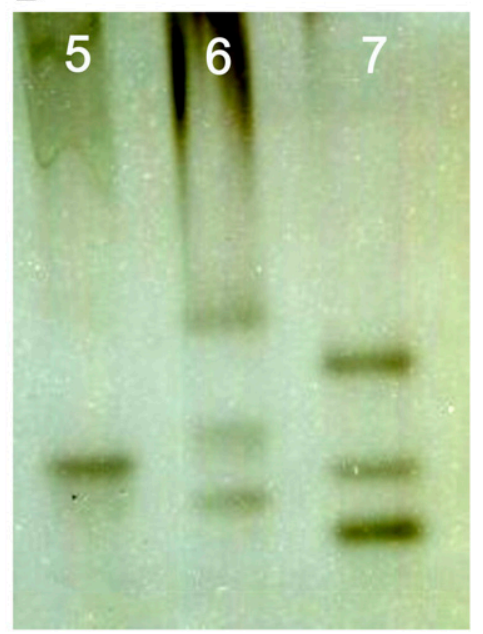

Fig. 2. Identification of the Meloidogyne populations collected from the Central Valley of Chile. A, Agarose gels using specific sequence-characterized amplified region markers. Lane 1: 1-kb ladder; lane 2: Meloidogyne arenaria (420-bp product, 2 populations); lane 3: M. javanica (670-bp product, 3 populations); lane 4: no amplification (15 populations). B, Isoenzymatic (b esterasis) patterns from Chilean Meloidogyne populations. Lane 5: M. arenaria (A1 type, 2 populations); lane 6: M. ethiopica, (E3 type, 15 populations); lane 7: M. javanica (J3 type, 3 populations). A1, E3, and J3 correspond to the classification by Carneiro et al. (2007). then the roots were weighed. To extract eggs from roots, roots were cut into small pieces and macerated in a blender at 14,500 rpm in a $0.2 \% \mathrm{NaOCl}$ solution for $30 \mathrm{~s}$, twice. Eggs were concentrated over nested 20-, 200-, and 500-mesh sieves and then suspended in tap water. J2 were extracted from the soil by a combination of the sieving and decanting method with Baermann's funnel (Christie and Perry 1951). The numbers of nematodes in samples were determined using a stereomicroscope.

The second test was performed in October 2014 with the same three rootstocks (Pomona, Nemaguard, and Marianna 2624) obtained from the same nurseries and grown under the same conditions as for the first evaluation. In this test, 10 replicates of each rootstock were used and inoculated, each with a mixture of 10,000 individuals (J2 + eggs). This inoculum contained an equal proportion of the six most aggressive isolates (i.e., those with the highest nematode reproduction in test 1$)$, with three M. javanica (mj1, mj2, and $\mathrm{mj} 3$ ) and three M. ethiopica (me5, me8, and me14) isolates combined. Nematode inoculation, duration of the test, and extraction of nematodes at the end of the study were identical to those in the first evaluation.

Rating and statistical analysis of the results. Data were analyzed separately using a one-way analysis of variance. In both tests, number of galls and nematode population density per plant were $\log _{10}(x+1)$ transformed prior to analysis. Galling and reproduction were compared with Tukey honestly significant difference test at $P \leq 0.05$. All the statistical analyses were carried out using the InfoStat Software (National University of Córdoba, Argentina). In the second test, the host response of rootstocks was rated, using a method derived from Pinochet et al. (1999), as follows: I = immune (absence of root galls; no nematodes in roots), $\mathrm{HR}=$ highly resistant (very low galling and final/initial numbers $<0.10$ ), $\mathrm{R}=$ resistant (low galling; $0.10<$ final/initial numbers $<1$ ), and $\mathrm{S}=$ susceptible (abundant galling; final/initial numbers $>1$ ).

\section{Results}

Identification and prevalence of Meloidogyne spp. in Chile. For all of the collected populations, all single-female isolates belonged to the same species (data not shown). Consequently, the survey did not detect any samples with mixed Meloidogyne spp. Based on PCR primers, two isolates of $M$. arenaria and three isolates of $M$. javanica were identified among the 20 total samples (Table 1; Fig. 2A). Identification based upon the specific iso-EST $\mathrm{b}$ pattern established that all other isolates belonged to the species $M$. ethiopica and confirmed the identity of the $M$. arenaria and $M$. javanica isolates (Table 1; Fig. 2B). The detection frequency of the three RKN species was 10,15 , and $75 \%$ for M. arenaria, M. javanica, and M. ethiopica, respectively. Our results illustrate that the most prevalent Meloidogyne sp. in Chile is $M$. ethiopica. Although $M$. arenaria and $M$. javanica were both detected on vegetable and grape crops, $M$. ethiopica was recovered at least once on all crops sampled. Hosts for $M$. ethiopica ranged from vegetables (cucumber and tomato) to grape and fruit crops such as Prunus spp. (peach and sour cherry) and kiwi.

Reproduction of Meloidogyne spp. on Prunus rootstocks. High gall numbers corresponded with high nematode densities, confirming the correlation between both evaluation criteria. The plum rootstock Marianna 2624 was completely free of galls and eggs and J2 were not recovered from roots or soil. Thus, this rootstock can be classified as immune to all Meloidogyne isolates evaluated here (Table 2)

The peach rootstock Pomona varied in host status to the diverse set of Meloidogyne isolates (Table 2). Considering both parameters (galling and reproduction), we identified three groups of isolates. A first group of six isolates (all three $M$. javanica isolates and the $M$. ethiopica isolates me5, me8, and me14) had reproduction rates $>1$. A second group contained both $M$. arenaria isolates and five other M. ethiopica isolates (me3, me4, me9, me11, and me12) that produced marked galling with low or intermediate reproduction rates. A third group contained only $M$. ethiopica isolates (me1, me2, me6, me7, me10, me13, and me15) that produced limited galling and low reproduction rates. Except for the M. javanica isolates to which Pomona was uniformly susceptible, this rootstock exhibited an isolate-dependent host suitability. 
The peach rootstock Nemaguard exhibited different levels of resistance as well. No Meloidogyne isolate reached a reproduction rate $>1$ but all three $M$. javanica isolates and four $M$. ethiopica isolates (me5, me8, me9, and me14) had intermediate reproduction rates $(0.23$ to 0.61 ), making Nemaguard resistant to these isolates. This rootstock expressed a high level of resistance to the remaining 13 isolates and, notably, to $M$. arenaria (ma1 and ma2) and $M$. ethiopica (me1 to $-4,-6-7,-10$ to -13 , and -15 ).

Taken together, the reproduction data obtained from Nemaguard and Pomona show that seven isolates (mj1, mj2, mj3, me5, me8, me9, and me14), had a higher reproduction rate on both rootstocks and can be considered as more aggressive than the other isolates evaluated.

Based upon galling and reproduction rates, data obtained from the second evaluation verified the host response obtained in the first evaluation (Table 3). Marianna was immune to a mixture of M. javanica and M. ethiopica isolates. Nemaguard was resistant, although it had noticeable galling. Pomona was susceptible and displayed the highest Meloidogyne reproduction rate and the highest galling.

\section{Discussion}

According to Starr and Mercer (2009), the first step to finding Meloidogyne-resistant genotypes is to have a good picture of the identity of the Meloidogyne spp. in the area of interest. Currently, 95 nominal Meloidogyne spp. have been identified worldwide (Perry et al. 2009; Skantar et al. 2008). Traditionally, the description and identification of Meloidogyne spp. are based on morphology and morphometrics. However, morphological identification is difficult, time consuming, and often inconclusive for individual specimens that vary considerably within a population (Perry et al. 2009; Tigano et al. 2005; Zijlstra et al. 2000). The incorporation of molecular techniques to identify plantparasitic nematodes has contributed to overcoming these limitations (Blok 2005; Carneiro et al. 2000, 2007; Esbenshade and Triantapyllou 1985, 1990; Meza et al. 2011, 2012; Perry et al. 2009; Powers et al. 1997). Using these techniques in a survey of Meloidogyne spp. in the Central Valley of Chile, our study detected the presence of three RKN species: $M$. ethiopica, $M$. javanica, and $M$. arenaria.

M. ethiopica, first described by Whitehead (1968) from East Africa, has been more recently redescribed by Carneiro et al. (2007). Of the
20 samples collected in this study, $75 \%$ of the isolates were identified as $M$. ethiopica. Our results are in agreement with those of Carneiro et al. (2007) and Aballay et al. (2009, 2013), who found M. ethiopica to be the most prevalent Meloidogyne sp. present in Chile. Until recently, using classical taxonomy methods, this species may have been confused with other Meloidogyne spp. (Carneiro et al. 2007). In the Central Valley of Chile, we confirmed that $M$. ethiopica has both a wide geographical distribution and a wide host range. Aballay et al. (2009) postulated that the severe damage to grape vines in the Central Valley was due to $M$. ethiopica. In comparison, $M$. javanica and $M$. arenaria were detected in only 15 and $10 \%$ of the samples, respectively. Surprisingly, $M$. incognita, the Meloidogyne sp. considered to have the highest economic impact worldwide (Abad et al. 2008), and M. hapla, another prominent Meloidogyne sp. (Opperman et al. 2008), were not found during our survey. However, a survey that includes other regions of Chile, notably northern and southern regions, is necessary to complete the identification and distribution of Meloidogyne spp. found in the country.

Table 3. Galling and reproduction of a mixture of the six most aggressive Chilean isolates, three from each Meloidogyne javanica and M. ethiopica, on three Prunus rootstocks ${ }^{\mathrm{w}}$

\begin{tabular}{lccc}
\hline Rootstock & $\begin{array}{c}\text { Number of galls per } \\
\text { plant }^{\mathbf{x}}\end{array}$ & $\begin{array}{c}\text { Final nematode } \\
\text { numbers }^{\mathbf{y}}\end{array}$ & Status $^{\mathbf{z}}$ \\
\hline Pomona & $143 \mathrm{a}$ & $14,054 \mathrm{a}$ & $\mathrm{S}$ \\
Nemaguard & $82 \mathrm{~b}$ & $3,979 \mathrm{~b}$ & $\mathrm{R}$ \\
Marianna & 0 & 0 & $\mathrm{I}$ \\
2624 & & & \\
\hline
\end{tabular}

${ }^{w}$ Within a column, values followed by the same letter are not significantly different according to Tukey's honestly significant difference test $(P=0.05)$.

${ }^{x}$ Data were transformed to $\log _{10}(x+1)$ for analysis; nontransformed data are presented. Values are the mean of 10 replicates.

y Final nematode numbers are total eggs per plant plus second-stage juveniles from soil.

${ }^{\mathrm{z}} \mathrm{S}=$ susceptible (abundant galling; final/initial numbers $>1$ ), $\mathrm{R}=$ resistant (low galling; $0.10<$ final/initial numbers $<1$ ), and $\mathrm{I}=$ immune (absence of root galls; no nematodes in roots).

Table 2. Galling and reproduction of 20 Chilean isolates of Meloidogyne spp. (root-knot nematodes [RKN]) on three Prunus rootstocks ${ }^{y}$

\begin{tabular}{|c|c|c|c|c|c|c|}
\hline \multirow[b]{2}{*}{ RKN species, code } & \multicolumn{3}{|c|}{ Number of galls per plant } & \multicolumn{3}{|c|}{ Final nematode numbers ${ }^{\mathrm{z}}$} \\
\hline & $\overline{\text { Pomona }}$ & Nemaguard & $\overline{\text { Marianna }}$ & Pomona & Nemaguard & Marianna \\
\hline \multicolumn{7}{|c|}{ Meloidogyne arenaria } \\
\hline ma1 & $107 \mathrm{bc}$ & $14 \mathrm{ab}$ & 0 & $2,038 \mathrm{ab}$ & $324 \mathrm{ab}$ & 0 \\
\hline ma2 & $110 \mathrm{bc}$ & $14 \mathrm{ab}$ & 0 & $1,449 \mathrm{ab}$ & $380 \mathrm{~b}$ & 0 \\
\hline \multicolumn{7}{|l|}{ M. javanica } \\
\hline mj1 & $161 \mathrm{c}$ & $130 \mathrm{c}$ & 0 & $11,253 \mathrm{c}$ & $6,110 \mathrm{~d}$ & 0 \\
\hline $\mathrm{mj} 2$ & $155 \mathrm{c}$ & $109 \mathrm{c}$ & 0 & $12,933 \mathrm{c}$ & $5,426 \mathrm{~d}$ & 0 \\
\hline $\mathrm{mj} 3$ & $162 \mathrm{c}$ & $113 \mathrm{c}$ & 0 & $12,998 \mathrm{c}$ & $3,995 \mathrm{~d}$ & 0 \\
\hline \multicolumn{7}{|l|}{ M. ethiopica } \\
\hline me1 & $49 \mathrm{a}$ & $8 \mathrm{ab}$ & 0 & $567 \mathrm{a}$ & $242 a b$ & 0 \\
\hline me2 & $47 \mathrm{a}$ & $6 a b$ & 0 & $900 \mathrm{ab}$ & $234 \mathrm{ab}$ & 0 \\
\hline me3 & $114 \mathrm{c}$ & $14 \mathrm{ab}$ & 0 & $2,917 \mathrm{ab}$ & $689 \mathrm{bc}$ & 0 \\
\hline me4 & $122 \mathrm{c}$ & $13 \mathrm{ab}$ & 0 & $1,478 \mathrm{ab}$ & $396 \mathrm{ab}$ & 0 \\
\hline me5 & $146 \mathrm{c}$ & $108 \mathrm{c}$ & 0 & $12,352 \mathrm{c}$ & $3,534 \mathrm{~d}$ & 0 \\
\hline me6 & $37 \mathrm{a}$ & $6 a b$ & 0 & $799 \mathrm{a}$ & $223 a b$ & 0 \\
\hline me7 & $50 \mathrm{a}$ & $22 a b$ & 0 & $1,527 \mathrm{ab}$ & $220 \mathrm{ab}$ & 0 \\
\hline me8 & $158 \mathrm{c}$ & $97 \mathrm{c}$ & 0 & $12,395 \mathrm{c}$ & $5,972 \mathrm{~d}$ & 0 \\
\hline me9 & $95 \mathrm{bc}$ & $53 \mathrm{bc}$ & 0 & $4,076 \mathrm{bc}$ & $2,353 \mathrm{~cd}$ & 0 \\
\hline me10 & $39 a$ & $5 \mathrm{a}$ & 0 & $1,006 \mathrm{ab}$ & $334 a b$ & 0 \\
\hline me11 & $124 \mathrm{c}$ & $15 \mathrm{ab}$ & 0 & $1,734 \mathrm{ab}$ & $182 \mathrm{a}$ & 0 \\
\hline me12 & $119 \mathrm{c}$ & $17 \mathrm{ab}$ & 0 & $2,035 \mathrm{ab}$ & $500 \mathrm{~b}$ & 0 \\
\hline me13 & $44 \mathrm{a}$ & $15 \mathrm{ab}$ & 0 & $1,340 \mathrm{ab}$ & $350 \mathrm{ab}$ & 0 \\
\hline me14 & $153 \mathrm{c}$ & $143 \mathrm{c}$ & 0 & $11,657 \mathrm{c}$ & $4,528 \mathrm{~d}$ & 0 \\
\hline me15 & $62 \mathrm{ab}$ & $9 \mathrm{ab}$ & 0 & $2,072 \mathrm{ab}$ & $462 \mathrm{~b}$ & 0 \\
\hline
\end{tabular}

y Actual data are presented but data were transformed to $\log _{10}(x+1)$ for analysis. Values are the mean of five replicates. Within the same column, values followed by the same letter are not significantly different according to Tukey test $(P=0.05)$.

${ }^{\mathrm{z}}$ Final nematode numbers are total eggs per plant plus second-stage juveniles from soil. 
The second part of our investigation was aimed at evaluating the reproduction of Chilean populations of Meloidogyne on the three Prunus rootstocks: Pomona, Nemaguard, and Marianna 2624. None of the Chilean Meloidogyne spp. or isolates were able to reproduce on Marianna 2624. This Prunus rootstock has been reported as resistant or immune to the prominent Meloidogyne spp. worldwide (Nyczepir and Esmenjaud 2008) but this is the first report of this rootstock being resistant to $M$. ethiopica. The broad-spectrum resistance of this genotype to Meloidogyne spp. makes it a promising source of material for breeding programs in Chile. The genetics of resistance are unknown in Marianna 2624, even though single dominant genes have been identified in some accessions of the closely related $P$. cerasifera (Myrobalan plum, $M a$ gene) (Claverie et al. 2004, 2011) and $P$. salicina (Japanese plum, Rjap gene) (Claverie et al. 2004). The $M a$ gene notably suppresses nematode multiplication and confers a complete-spectrum, high-level, and heat-stable resistance to $M$. arenaria, $M$. incognita, M. javanica, M. floridensis, and M. enterolobii (Esmenjaud et al. 2009; Nyczepir and Esmenjaud 2008).

Pomona, the second peach rootstock evaluated, has been used as a reference susceptible accession. Although our results overall confirmed its susceptible response to Meloidogyne spp., its host suitability varied unexpectedly from susceptible to highly resistant. Despite marked galling, reproduction rates of some isolates were $<1$. This situation reflects that reproduction of particular isolates may be limited on this rootstock, suggesting that isolate-specific mechanisms inhibit females from producing high egg numbers. This Meloidogyne isolatespecific response has also been reported in GF-305, another susceptible peach rootstock (Esmenjaud et al. 1994; Marull et al. 1994). The differential response observed in Pomona might be attributed to the high pathogenic diversity of Meloidogyne spp., as previously reported (Esmenjaud et al. 1994; Nyczepir and Esmenjaud 2008; Semblat et al. 2000). In our work, we illustrated this marked diversity in susceptibility in M. ethiopica, a situation that had never been reported in this or other Chilean Meloidogyne spp.

Nemaguard was resistant or highly resistant to Chilean Meloidogyne isolates. Notably, it expressed a high level of resistance to $M$. arenaria and to most isolates of $M$. ethiopica. By contrast, resistance was less pronounced to all three $M$. javanica isolates and to a set of three M. ethiopica isolates; this result was confirmed when Nemaguard was challenged with a mixed population of $M$. javanica and M. ethiopica. These results demonstrate that using this rootstock does not guarantee suppression of Meloidogyne populations in the field. Thus, our results are similar to those from Mella and Sotomayor (2005), stating that, for one unidentified Meloidogyne population, nematode densities remained constant on Nemaguard after 2 years in high-volume containers. Sherman and Lyrene (1983) also reported galling by Meloidogyne spp. on Nemaguard in Chile, even though the nematode species was also not identified.

Interestingly, we observed that the isolates with the highest reproduction rates were the same in Nemaguard and in Pomona. This highlights the interest of these isolates for inclusion in future Meloidogyne rootstock evaluation. Similar highly virulent Meloidogyne spp. have been reported for a set of populations evaluated on various tomato accessions (Sorribas and Verdejo-Lucas 1999).

Our results illustrate that Prunus sources have three types of resistance to Meloidogyne spp. First, resistance may be conferred to all the tested species of this genus, as in the accession Marianna 2624. This type of resistance has also been characterized in Myrobalan plum accessions P.2175 and P. 2980 with the resistance gene $M a$ (Esmenjaud et al. 1997). Second, resistance may depend on the species of Meloidogyne considered. Such a species-specific resistance has been described in the almond-peach hybrid GF557 that is resistant to $M$. arenaria but susceptible to $M$. javanica (Esmenjaud et al. 1994). In our study, Nemaguard showed a less marked difference in resistance between these two Meloidogyne spp. because it was highly resistant to $M$. arenaria (two isolates) but only moderately resistant to $M$. javanica (three isolates). Finally, resistance may also depend on the isolate from the same Meloidogyne sp., as previously shown in the susceptible peach rootstock GF305 (Esmenjaud et al. 1994). We have reported here a similar isolate-specific resistance of Pomona to M. ethiopica.
Resistance sources are most often evaluated with a single Meloidogyne isolate per species and, therefore, may have been erroneously considered to display species-specific resistance when actually displaying isolate-specific resistance. In future rootstocks evaluations, a range of isolates from a single Meloidogyne species should be systematically used in order to evaluate the variability of the plant response. With this approach, the final rootstock resistance behavior will be known by selecting the more aggressive isolates and using them in mixture, as we did in our second evaluation test.

\section{Acknowledgments}

We thank the Instituto de Investigaciones Agropecuarias and the National CONICYT-FONDECYT project number 11121209 in Chile for funding this research.

\section{Literature Cited}

Abad, P., Gouzy, J., Aury, J.-M., Castagnone-Sereno, P., Danchin, E. G. J. Deleury, E., Perfus-Barbeoch, L., Anthouard, V., Artiguenave, F., Blok, V. C., Caillaud, M.-C., Coutinho, P. M., Dasilva, C., De Luca, F., Deau, F., Esquibet, M., Flutre, T., Goldstone, J. V., Hamamouch, N., Hewezi, T., Jaillon, O., Jubin, C., Leonetti, P., Magliano, M., Maier, T. R., Markov, G. V., McVeigh, P., Pesole, G., Poulain, J., Robinson-Rechavi, M., Sallet, E., Ségurens, B. Steinbach, D., Tytgat, T., Ugarte, E., van Ghelder, C., Veronico, P., Baum, T. J., Blaxter, M., Bleve-Zacheo, T., Davis, E. L., Ewbank, J. J., Favery, B., Grenier, E., Henrissat, B., Jones, J. T., Laudet, V., Maule, A. G., Quesneville, H., Rosso, M-N., Schiex, T., Smant, G., Weissenbach, J., and Wincker, P. 2008. Genome sequence of the metazoan plant-parasitic nematode Meloidogyne incognita. Nat. Biotechnol. 26:909-915.

Aballay, E., Ordenes, P., Martensson, A., and Persson, P. 2013. Effects of rhizobacteria on parasitism by Meloidogyne ethiopica on grapevines. Eur. J. Plant Pathol. 135:137-145.

Aballay, E., Persson, P., and Martensson, A. 2009. Plant-parasitic nematodes in Chilean vineyards. Nematropica 39:85-97.

Blok, V. 2005. Achievements in and future prospects for molecular diagnostics of plant parasitic nematodes. Can. J. Plant Pathol. 27:176-185.

Carneiro, R. M. D. G., Almeida, M. R. A., Cofcewicz, E. T., Magunacelaya, J. C., and Aballay, E. 2007. Meloidogyne ethiopica, a major root-knot nematode parasitizing Vitis vinifera and other crops in Chile. Nematology 9:633-639.

Carneiro, R. M. D. G., Almeida, M R. A.., and Quénéhervé, P. 2000. Enzyme phenotypes of Meloidogyne spp. populations. Nematology 2:645-654.

Christie, J., and Perry, V. 1951. Removing nematodes from soil. Proc. Helminthol. Soc. Wash. 18:106-108.

Claverie, M., Bosselut, N., Lecouls, A. C., Voisin, R., Lafargue, B., Poizat, C., Kleinhentz, M., Laigret, F., Dirlewanger, E., and Esmenjaud, D. 2004 Location of independent root-knot nematode resistance genes in plum and peach. Theor. Appl. Genet. 108:765-773.

Claverie, M., Dirlewanger, E., Bosselut, N., Van Ghelder, C., Voisin, R., Kleinhentz, M., Lafargue, B., Abad, P., Rosso, M., Chalhoub, B., and Esmenjaud, D. 2011. The $M a$ gene for complete-spectrum resistance to Meloidogyne species in Prunus is a TNL with a huge repeated C-terminal post-LRR region. Plant Physiol. 156:779-792.

Dalmasso, A., and Bergé, J. B. 1978. Molecular polymorphism and phylogenetic relationship in some Meloidogyne spp. application to the taxonomy of Meloidogyne. J. Nematol. 10:323-332.

Duval, H., Hoerter, M., Polidori, J., Confolent, C., Masse, M., Moretti, A., Van Ghelder C., and Esmenjaud, D. 2014. High-resolution mapping of the RMia gene for resistance to root-knot nematodes in peach. Tree Genet. Genomes 10:297-306.

Esbenshade, P., and Triantapyllou, A. 1985. Use of enzyme phenotypes for identification of Meloidogyne species. J. Nematol. 17:6-20.

Esbenshade, P., and Triantapyllou, A. 1990. Isozyme phenotypes for identification of Meloidogyne species. J. Nematol. 22:10-15.

Esmenjaud, D., Minot, J., Voisin, R., Pinochet, J., Simard, M., and Salesses, G. 1994. Inter- and intraspecific resistance variability in Myrobalan plum, peach, and peach-almond rootstock using 22 root-knot nematode populations. J. Am. Soc. Hortic. Sci. 119:94-100.

Esmenjaud, D., Minot, J., Voisin, R., Pinochet, J., Simard, M. H., and Salesses, G. 1997. Differential response to root-knot nematodes in Prunus species and correlative genetic implications. J. Nematol. 29:370-380.

Esmenjaud, D., Voisin, R., Van Ghelder, C., Bosselut, N., Lafargue, B., Di Vito, M., Dirlewanger, E., Poessel, J., and Kleinhentz, M. 2009. Genetic dissection of resistance to root-knot nematodes Meloidogyne spp. in plum, peach, almond, and apricot from various segregating interspecific Prunus progenies. Tree Genet. Genomes 5:279-289.

Fernández, C., Pinochet, J., Esmenjaud, D., Salesses, G., and Felipe, A. 1994 Resistance among new Prunus rootstocks and selections to root-knot nematodes from Spain and France. HortScience 29:1064-1067.

González, H. 2007. Nematodos fitoparásitos que afectan a frutales y vides en Chile Bol. INIA 149. Instituto de Investigaciones Agropecuarias, Santiago, Chile.

Hussey, R., and Barker, K. 1973. A comparison of methods of collecting inocula of Meloidogyne spp., including a new technique. Plant Dis. Rep. 57:1025-1028. 
Khallouk, S., Voisin, R., Van Ghelder, C., Engler, G., Amiri, S., and Esmenjaud, D. 2011. Histological mechanisms of the resistance conferred by the $M a$ gene against Meloidogyne incognita on Prunus spp. Phytopathology 101: 945-951.

Magunacelaya, J., and Dagnino, E. 1999. Nematología Agrícola en Chile. Serie Ciencias Agronómicas, No. 2. Facultad de Ciencias Agronómicas, Universidad de Chile, Santiago, Chile.

Marull, J., Pinochet, J., Felipe, A., and Cenis, J. 1994. Resistance verification in Prunus selections to a mixture of thirteen Meloidogyne isolates and resistance mechanisms of a peach-almond hybrid to $M$. javanica. Fundam. Appl. Nematol. 17:85-92.

Mella, P., and Sotomayor, C. 2005. Portainjertos para durazneros resistentes a nemátodos. Agron. For. Univ. Católica Chile 24:20-25.

Meza, P., Aballay, E., and Hinrichsen, P. 2011. Molecular and morphological characterisation of species within the Xiphinema americanum-group (Dorylaimida: Longidoridae) from the Central Valley of Chile. Nematology 13: 295-306.

Meza, P., Aballay, E., and Hinrichsen, P. 2012. Morphological and molecular characterization of Xiphinema index Thorne and Allen, 1950 (Nematoda: Longidaridae) isolates from Chile. Nematropica 42:41-47.

Nyczepir, A., and Esmenjaud, D. 2008. Nematodes. Pages 505-535 in: The Peach: Botany, Production and Uses. D. Layne and D. Bassi, eds. CABI Publishing, Wallingford, Oxon, UK.

Opperman, C., Bird, D., Williamson, V., Rokhsar, D., Burke, M., Cohn, J., Cromer, J., Diener, S., Gajan, J., Graham, S., Houfek, T., Liu, Q., Mitros, T., Schaff, J., Schaffer, R., Scholl, E., Sosinski, B., Thomas, V., and Windham, E. 2008. Sequence and genetic map of Meloidogyne hapla: A compact nematode genome for plant parasitism. Proc. Nat. Acad. Sci. USA 105:14802-14807.

Perry, R., Moens, M., and Starr, J. 2009. Meloidogyne species: A diverse group of novel and important plant parasites. Pages 1-17 in: Root-Knot Nematodes. R. Perry, M. Moens, and J. Starr, eds. CABI Publishing, Wallingford, Oxon, UK.

Pinochet, J. 1997. Breeding and selection for resistance to root-knot and lesion nematodes in Prunus rootstocks adapted to Mediterranean conditions. Phytoparasitica 25:271-274.

Pinochet, J. 2009. "Greenpac", a new peach hybrid rootstock adapted to Mediterranean conditions. HortScience 44:1456-1457.

Pinochet, J., Calvet, C., Hernández-Dorrego, A., Bonet, A., Felipe, A., and Moreno, M. 1999. Resistance of peach and plum rootstock from Spain, France and Italy to root-knot nematode Meloidogyne javanica. HortScience $34: 1259-1262$
Powers, T., Todd, T., Burnell, P., Murray, C., Fleming, C., Szalanski, A., Adams, B., and Harris, T. 1997. The rDNA internal transcribed spacer region as a taxonomic marker for nematodes. J. Nematol. 29:441-450.

Radwan, M., Farrag, S., Abu-Elamayem, M., and Ahmed, N. 2012. Biological control of the root-knot nematode, Meloidogyne incognita on tomato using bioproducts of microbial origin. Appl. Soil Ecol. 56:58-62.

Semblat, J., Bongiovanni, M., Wajnberg, A., Dalmasso, A., Abad, P., and CastegnoneSereno, P. 2000. Virulence and molecular diversity of parthenogenetic root-knot nematodes, Meloidogyne spp. Heredity 84:81-89.

Sherman, W., and Lyrene, P. 1983. Improvement of peach rootstock resistant to root-knot nematodes. Proc. Fla. State Hortic. Soc. 96:207-208.

Skantar, A., Carta, L., and Handoo, Z. 2008. Molecular and morphological characterization of an unusual Meloidogyne arenaria population from Traveler's Tree, Ravenala madagascariensis. J. Nematol. 40:179-189.

Sorribas, F., and Verdejo-Lucas, S. 1999. Capacidad parasitaria de Meloidogyne spp. en cultivares de tomate resistente. Investigación Agraria. Prod. Prot. Veg. 14:237-247.

Starr, J., and Mercer, C. 2009. Development of resistant varieties. Pages 326-337 in: Root-Knot Nematodes. R. Perry, M. Moens, and J. Starr, eds. CABI Publishing, Wallingford, Oxon, UK.

Tigano, M. S., Carneiro, R. M. D. G., Jeyaprakash, A., Dickson, D. W., and Adams, B. J. 2005. Phylogeny of Meloidogyne spp. based on $18 \mathrm{~S}$ rDNA and the intergenic region of mitochondrial DNA sequences. Nematology 7:851-862.

Van Ghelder, C., Lafargue, B., Dirlewanger, E., Ouassa, A., Voisin, R., Polidori, J., Kleinhentz, M., and Esmenjaud, D. 2010. Characterization of the RMja gene for resistance to root-knot nematodes in almond: Spectrum, location, and interest for Prunus breeding. Tree Genet. Genomes 6:503-511.

Verdejo-Lucas, S., and Talavera, M. 2009. Integrated management of nematodes parasitic on Prunus spp. Pages 177-194 in: Integrated Management of Fruit Crops and Forest Nematodes. A. Ciancio and G.Mukerji, eds. Springer Science Media, New York.

Whitehead, A. G. 1968. Taxonomy of Meloidogyne (Nematoda: Heteroderidae) with description of four new species. Trans. Zool. Soc. Lond. 31:263-401.

Zijlstra, C. 2000. Identification of Meloidogyne chitwoodi, M. fallax and M. hapla based on SCAR-PCR: A powerful way of enabling reliable identification of populations or individuals that share common traits. Eur. J. Plant Pathol. 106: 283-290

Zijlstra, C., Donkers-Venne, D. T. H. M., and Fargette, M. 2000. Identification of Meloidogyne incognita, $M$. javanica and $M$. arenaria using sequence characterised amplified region (SCAR) based PCR assays. Nematology 2 847-853. 